\title{
Feeding high oleic acid soybeans in place of conventional soybeans increases milk fat concentration
}

\author{
K. A. Weld and L. E. Armentano ${ }^{1}$ \\ Department of Dairy Science, University of Wisconsin, Madison 53706
}

\begin{abstract}
It is well established in the literature that feeding free vegetable oils rich in oleic acid results in greater milk fat secretion than does feeding linoleic-rich oils. The objectives of these experiments were to analyze the effects of oleic and linoleic acid when fed in the form of full-fat soybeans and the interaction between soybean particle size and fatty acid (FA) profile. Soybeans were included in diets on an iso-ether extract basis and diets were balanced for crude protein using soybean meal. Experiment 1 used 63 cows (28 primiparous, PP; 35 multiparous, MP) housed in a freestall barn with Insentec roughage intake control gates (Marknesse, the Netherlands). Cows were divided into 4 mixed parity groups within the same pen. Two groups were assigned to each of the 2 diets: whole raw Plenish (WP, high oleic; Dupont-Pioneer, Johnston, IA) soybeans or whole raw conventional (WC, high linoleic) soybeans. The MP cows exhibited significantly increased milk fat yield on the WP diet compared with the WC diet. A significantly greater $\mathrm{C} 18$ milk FA yield by the MP cows fed WP was observed compared with those fed WC, but no difference was present in the $\mathrm{C} 16$ or short-chain FA yield. No effects were seen in the PP cows. Experiment 2 used 20 cows (10 PP, $10 \mathrm{MP}$ ) in 2 balanced $5 \times 5$ Latin squares within parity. Cows received 5 diets: raw WP and WC diets, raw ground Plenish and conventional soybean diets (GP and GC, respectively), and a low fat control. A significant benefit was found for the GP diet compared with the GC diet for milk fat concentration and yield. In experiment 2 , no difference was observed between cows fed the WP compared with the $\mathrm{WC}$ diet. In experiment 2, cows consuming the Plenish diets produced less milk than when consuming the conventional soybean diets. The soybean diets resulted in significantly more $\mathrm{C} 18$ and less $<\mathrm{C} 18 \mathrm{FA}$
\end{abstract}

Received January 25, 2018.

Accepted July 12, 2018.

${ }^{1}$ Corresponding author: learment@wisc.edu compared with the low fat diet. The GP diet resulted in significantly more C18 FA than the GC diet and the ground soybeans resulted in less C16 FA compared with whole soybeans. In both experiments, cows fed the Plenish diets exhibited decreased trans-10 18:1, a FA often increased during milk fat depression, compared with those fed the conventional soybean diets, though differences were not observed in trans-10, cis-12 conjugated linoleic acid. These results indicate that feeding whole soybeans rich in oleic acid may result in some increased milk fat secretion compared with conventional whole soybeans containing high levels of linoleic acid. This advantage is clear for ground high-oleic soybeans compared with ground conventional soybeans.

Key words: oleic acid, linoleic acid, milk fatty acid, milk fat depression, bioactive fatty acid

\section{INTRODUCTION}

For high-producing dairy cattle, especially in early lactation, production is limited by energy availability. While increasing the starch portion of the diet can increase digestible energy content, it also puts cows at risk for acidosis (Owens et al., 1998). The addition of dietary fat in the form of a pure fat or a full-fat oilseed is an alternative option for increasing the energy density of the diet.

Adding long-chain fatty acids (LCFA) to the diet has the potential to increase milk fat secretion due to increased absorption of fatty acids (FA), which can be incorporated into milk fat. However, dietary UFA may decrease milk fat through the production of bioactive FA in the rumen, which can downregulate milk fat secretion (Griinari et al., 1998; Khiaosa-Ard et al., 2015). The most widely recognized bioactive FA is trans-10, cis-12 $(\boldsymbol{t} \mathbf{1 0}, \boldsymbol{c 1 2})$ CLA. Other CLA have similar effects on mammary gland gene expression as well, but not all CLA are bioactive (Perfield et al., 2006, 2007). In addition to the effects of $t 10, c 12$ CLA and other less characterized CLA, the monoene trans-10 18:1 ( $\boldsymbol{t 1 0}$ 18:1), may also inhibit milk fat secretion (Shingfield et al., 2009). However, t10 18:1 is much less potent than $t 10, c 12$ CLA, although it is absorbed in 
much greater quantities than CLA (Shingfield et al., 2009) and other research has shown no effect of $t 10$ 18:1 on milk fat secretion (Lock et al., 2007). The inhibition of short-chain fatty acid (SCFA) synthesis may be compensated for by the increase in LCFA availability and uptake. This results in a change in FA profile of milk toward LCFA whenever FA are supplemented to the diet, even when total milk fat secretion may not be decreased. Additionally, milk fat has the potential to be increased if SCFA synthesis is less inhibited (He et al., 2012; Stoffel et al., 2015).

It is well established in the literature that dietary oils containing high linoleic acid (LA) cause less milk fat secretion those oils containing high levels of oleic acid (OA; He et al., 2012; Stoffel et al., 2015; Dorea and Armentano, 2017). This effect is due to greater depression of FA synthesis by the mammary gland, as well as lower transfer of LCFA into the mammary gland, both effects observed when pure $t 10, c 12$ CLA is added to otherwise iso-FA diets (see Figure 1 in Dorea and Armentano, 2017 for review). The "normal" biohydrogenation pathway for LA does not include the production of $t 10, c 12$ CLA. Only when the main pathway is overwhelmed or the bacterial profile is shifted (Weimer et al., 2010) are significant quantities of $t 10, c 12$ CLA produced from LA. Although dietary OA can decrease secretion of milk SCFA, the mechanism of this effect is not well established. Oleic acid is probably not converted to $t 10, c 12$ CLA, even under acidic conditions (Mosley et al., 2002). However, OA can be converted to $t 10$ 18:1, which may be directly inhibitory to milk SCFA secretion (Shingfield et al., 2009). An alternative explanation for the OA induced inhibition of milk de novo fatty acid secretion is that feeding OA could indirectly increase $t 10, c 12$ CLA production from dietary LA. Either or both of these may explain how OA reduces milk SCFA secretion, potentially causing milk fat depression (MFD), though other possible mechanisms may also exist.

With the development of new soybean varieties, such as Plenish (high oleic; Dupont-Pioneer, Johnston, IA) soybeans, the comparison of LA and OA within soybeans is now possible. The first objective of these experiments was to determine the effects of OA versus LA full-fat whole raw soybeans on milk fat concentration and yield. The second objective was to evaluate the difference in their effects when those soybeans were fed ground or whole, as grinding the soybeans is likely to increase the potential for bioactive FA formation. We hypothesized that cows fed Plenish soybeans would yield greater milk fat than those fed conventional soybeans, with increased yield of both short and LCFA. Also, we expected this difference would be enhanced by grinding the 2 different types of soybeans.

\section{MATERIALS AND METHODS}

All protocols were approved by the University of Wisconsin-Madison Institutional Animal Care and Use Committee.

\section{Experiment 1}

Cows and Diets. Sixty-three cows $[28$ primiparous (PP), 35 multiparous (MP)] were randomly assigned to 4 mixed parity groups. Cows averaged $111 \pm 20$ (mean \pm SD) DIM at the beginning of the covariate period. Cows were housed in a single freestall pen with 32 Insentec Roughage Intake Control (RIC) gates (Marknesse, the Netherlands) at the Emmons Blaine Research Farm (Arlington, WI). Cows were milked twice daily and fed once daily.

Whole raw soybeans were included in the treatment diets on an iso-ether extract basis, based on preliminary samples of soybeans. Dietary $\mathrm{CP}$ was balanced to $17.5 \%$ with soybean meal according to the NRC (NRC, 2001; Table 1). The soybeans differed in their FA profile as intended. The Plenish soybeans were high in OA compared with the conventional soybeans which were high in LA (Table 2). Diets were adjusted weekly based on forage DM according to NIR spectroscopy (AgriNIR, Dinamica Generale, St. Charles, IL).

The 32 RIC gates in the pen were randomly assigned to 4 different groups of 8 RIC gates. Each of the 4 mixed parity groups of cows was randomly assigned to 1 of 4 sets of RIC gates in the same physical pen so that a group of 16 cows had access to a group of 8 RIC gates that all contained one diet. During an 8-wk covariate period, 4 sets of gates contained identical diets composed of $28.5 \%$ concentrate mix, $4.5 \%$ distillers grains, $4.8 \%$ cottonseed, $12.7 \%$ high-moisture corn, $28.1 \%$ corn silage, and $21.4 \%$ alfalfa haylage on a DM basis. After the covariate period, 2 groups of gates were randomly assigned to the Plenish diet and the remaining 2 groups of gates were assigned to the conventional diet for $3 \mathrm{wk}$ without crossover.

Sample Collection and Analysis. Samples of all diet components were collected on a weekly basis and immediately frozen at $-20^{\circ} \mathrm{C}$. Later they were dried at $55^{\circ} \mathrm{C}$ in a forced-air oven for $48 \mathrm{~h}$ and ground in a Wiley mill to pass through a 2 -mm screen. Samples were then dried at $105^{\circ} \mathrm{C}$ for $24 \mathrm{~h}$ to get an absolute DM. Samples were composited within diet component and within the covariate and treatment periods for nutrient analysis. Dairyland Laboratories (Arcadia, WI) analyzed for NDF (method 2002.04, AOAC International, 2012), ether extract (method 2003.05, AOAC International, 2012), CP (method 990.03, AOAC International, 2012), and ash (method 942.05, AOAC International, 2012). 
Feed FA were determined at University of WisconsinMadison according to Sukhija and Palmquist (1988). The composition of the TMR was calculated mathematically based on the individual analyses of components. Total mixed ration samples were analyzed for particle size using the Penn State Particle Separator.

Milk samples were taken the last $3 \mathrm{~d}, 6$ consecutive milkings, of the covariate period and d 17 to 21 of the treatment period, 10 consecutive milkings. Samples were preserved with bronopol and sent to Agsource (Menomenie, WI) for analysis. Samples from the middle 2 milkings for both the covariate and treatment collection periods were collected into additional vials containing no preservative, composited based on milk yield, and analyzed for FA. Milk FA were extracted and methylated according to Chouinard et al. (1999). Milk FA were determined utilizing gas-liquid chromatography (WCOT fused silica, $100 \mathrm{~m} \times 0.25 \mathrm{~mm}$ column

Table 1. Ingredient and chemical composition of experimental diets for experiments 1 and 2

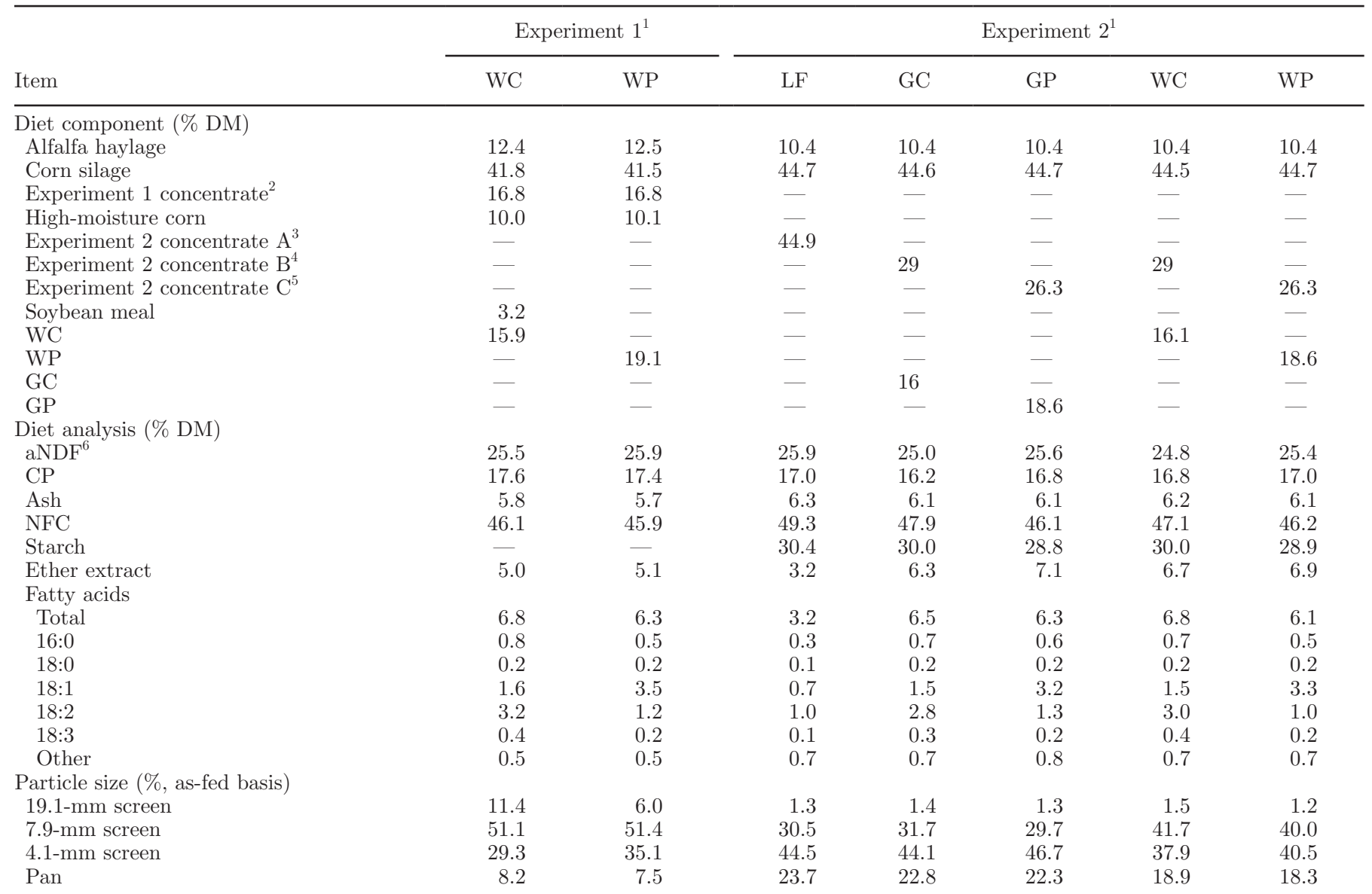

${ }^{1} \mathrm{LF}=$ low fat; GC = ground conventional; GP = ground Plenish (Dupont-Pioneer, Johnston, IA); WC = whole conventional; WP $=$ whole Plenish.

${ }^{2}$ Composition on an as-fed basis: $78 \%$ fine ground corn (mean particle size $500 \mu \mathrm{m}$ ), $12.3 \%$ corn gluten meal, $2.2 \%$ salt, $2.2 \%$ calcium carbonate, $2 \%$ trace mineral pack (includes monensin 1.2\% DM), 1.2\% monodicalcium phosphate, $1 \%$ magnesium oxide, $0.7 \%$ Dynamate (Mosaic Co., Plymouth, MN).

${ }^{3}$ Composition on an as-fed basis: $46.7 \%$ fine ground corn (mean particle size $500 \mu \mathrm{m}$ ), $36.8 \%$ soybean meal, $4.3 \%$ soy hull pellets, $3.3 \%$ expelled Plenish soybeans (Landus Cooperative, Ames, IA), 3.3\% Soy Plus (Landus Cooperative), 1.7\% canola meal, $1.1 \%$ calcium carbonate, $0.8 \%$ trace mineral pack (includes monensin 1.2\% DM), $0.8 \%$ salt, $0.5 \%$ magnesium oxide, $0.3 \%$ Dynamate (Mosaic Co.), $0.3 \%$ monodicalcium phosphate, $0.2 \%$ Smartamine M (Adisseo, Alpharetta, GA).

${ }^{4}$ Composition on an as-fed basis: $68.9 \%$ fine ground corn (mean particle size $500 \mu \mathrm{m}$ ), $17 \%$ Soy Plus (Landus Cooperative), $5.3 \%$ soybean meal, $2.6 \%$ canola meal, $1.8 \%$ calcium carbonate, $1.3 \%$ trace mineral pack (includes monensin $1.2 \%$ DM), $1.3 \%$ salt, $0.6 \%$ magnesium oxide, $0.5 \%$ Dynamate (Mosaic Co.), 0.5\% monodicalcium phosphate, 0.3\% Smartamine M (Adisseo).

${ }^{5}$ Composition on an as-fed basis: $71.7 \%$ fine ground corn (mean particle size $500 \mu \mathrm{m}$ ), $18.6 \%$ expelled Plenish soybeans (Landus Cooperative), $2.8 \%$ canola meal, $1.9 \%$ calcium carbonate, $1.4 \%$ trace mineral pack (includes monensin $1.2 \%$ DM), $1.4 \%$ salt, $0.7 \%$ magnesium oxide, $0.5 \%$ Dynamate (Mosaic Co.), 0.5\% monodicalcium phosphate, 0.3\% Smartamine M (Adisseo).

${ }^{6}$ aNDF $=$ neutral detergent fiber determined with procedure using $\alpha$-amylase. 
coated in CP-Sil88, Varian Inc., Walnut Creek, CA). The injector and flame ionization detector temperatures were $255^{\circ} \mathrm{C}$. The initial column temperature was $50^{\circ} \mathrm{C}$ and increased $4^{\circ} \mathrm{C}$ per minute to a final temperature of $190^{\circ} \mathrm{C}$. Helium was used as the carrier gas.

Statistical Analysis. Of the 63 cows, 1 was physically removed from the study partway through the treatment period due to extreme lameness, and 1 experienced a displaced abomasum during the last week of the covariate and was excluded from analysis. Although an RIC gate does not open for cows not assigned to that gate, some cows reach over the closed gate and can consume the unassigned diet. This intake is recorded and properly assigned to that cow. In all, 11 cows consumed more than $5 \%$ of their daily as-fed intake from gates with their nonassigned diet, and these cows were excluded from the final analysis. The final analysis included $17 \mathrm{MP}$ cows assigned to conventional, $11 \mathrm{MP}$ cows assigned to Plenish, $9 \mathrm{PP}$ cows assigned to conventional, and $13 \mathrm{PP}$ cows assigned to Plenish.

Proc Mixed with Kenward-Roger degrees of freedom (45 df) in SAS 9.4 (SAS Institute Inc., Cary, NC) was used for analysis. The model contained the fixed effects of the covariate, parity, treatment, and parity $x$ treatment, and the random effect of group and cow within group $\times$ treatment. Group did not explain any variation, as expected due to their random nature, and therefore the error term for testing main effects defaulted to cow. Due to the presence of an interaction, treatment comparisons within parity were done. The reported least squares means were adjusted based on the covariate mean of MP and PP animals separately.

Table 2. Soybean nutrient information for experiments 1 and $2^{1}$

\begin{tabular}{|c|c|c|c|c|c|c|}
\hline \multirow[b]{2}{*}{ Item } & \multicolumn{2}{|c|}{ Experiment 1} & \multicolumn{4}{|c|}{ Experiment 2} \\
\hline & WC & WP & GC & GP & WC & WP \\
\hline $\mathrm{CP}(\%$ of $\mathrm{DM})$ & 42.4 & 43.1 & 38.5 & 40.5 & 41.6 & 41.9 \\
\hline $\mathrm{EE}^{2}(\%$ of $\mathrm{DM})$ & 17.8 & 15.8 & 21.4 & 20.7 & 23.4 & 20 \\
\hline Total FA ( $\%$ of DM) & 29.0 & 22.2 & 25.1 & 21.0 & 26.8 & 19.8 \\
\hline \multicolumn{7}{|l|}{$\mathrm{FA}^{3}(\mathrm{~g} / 100 \mathrm{~g}$ of $\mathrm{FA})$} \\
\hline $12: 0$ & 2.1 & 3.5 & 2.0 & 2.1 & 2.0 & 2.7 \\
\hline 14:0 & 0.6 & 0.9 & 1.5 & 1.1 & 0.6 & 0.8 \\
\hline 16:0 & 10.2 & 5.8 & 9.5 & 6.5 & 9.8 & 6.0 \\
\hline $18: 0$ & 4.1 & 3.5 & 3.7 & 3.5 & 3.8 & 3.5 \\
\hline $18: 1$ & 25.2 & 73.9 & 26.2 & 65.4 & 24.7 & 71.9 \\
\hline $18: 2$ & 48.2 & 6.1 & 47.1 & 13.3 & 48.9 & 7.7 \\
\hline $18: 3$ & 5.6 & 1.6 & 5.7 & 2.3 & 6.0 & 1.7 \\
\hline Other FA & 6.6 & 9.2 & 4.2 & 8.2 & 4.3 & 5.7 \\
\hline
\end{tabular}

${ }^{1} \mathrm{GC}=$ ground conventional; GP $=$ ground Plenish (Dupont-Pioneer, Johnston, IA); $\mathrm{WC}=$ whole conventional; $\mathrm{WP}=$ whole Plenish.

${ }^{2} \mathrm{EE}=$ ether extract.

${ }^{3} \mathrm{FA}=$ fatty acid.

\section{Experiment 2}

Cows and Diets. Twenty cows (10 PP, 10 MP) were randomly assigned within parity to 2 balanced $5 \times 5$ Latin squares. Cows were $88 \pm 10$ (mean \pm SD) DIM at the beginning of the experiment. Cows were housed in tie stalls in the Dairy Cattle Center (Madison, WI) for the duration of the experiment. Cows were milked twice daily, fed once daily, and allowed to exercise for approximately $1 \mathrm{~h}$ each morning. Five diets were fed: a low fat control ( $\mathbf{L F}$ ), and diets containing ground raw Plenish soybeans (GP), ground raw conventional soybeans (GC), whole raw Plenish soybeans (WP), or whole raw conventional soybeans (WC) in 14-d periods. The soybeans were added to the diets on an isoether extract basis and diets were balanced for $17.5 \%$ CP with soybean meal (NRC, 2001; Table 1). In the low fat diet soybeans were replaced with corn, soybean hulls, and soybean meal.

Ground soybeans were ground using a Jacobs Hammer Mill with a $0.191(\# 12)$ perforated $\times 0.188$ gauge screen (Jacobs Corporation, Harlan, IA), and bagged on a weekly basis to minimize any possible difference in oxidation between treatments. Whole soybeans of both varieties were delivered in bulk at the beginning of the experiment.

Sample Collection and Analysis. Individual feed components, TMR, and orts were sampled weekly. Diets were adjusted weekly based on DM determination of forages at $55^{\circ} \mathrm{C}$ for $48 \mathrm{~h}$. Samples were dried and analyzed as described for experiment 1 with the addition of analysis for starch by Dairyland Laboratories (AOAC method 2014.10; Hall, 2015). Milk samples were collected into vials containing bronopol and analyzed for d 12 to 14 of each period (6 consecutive milkings). The middle samples were collected into additional vials without preservative and used for the determination of milk FA as described for experiment 1. Orts and TMR samples were analyzed for particle size using the Penn State Particle Separator.

Statistical Analysis. Analysis was done using Proc Mixed in SAS 9.4 (SAS Institute Inc., Cary, NC) with Kenward-Roger degrees of freedom. The model included the fixed effects of treatment, period, parity, parity $\times$ period, and treatment $\times$ parity, and a random effect of cow within parity. Preplanned contrasts included control (low-fat) versus all soybean supplemented diets and the interaction of soybean type and particle size. If the $P$-value of the interaction of type and particle size was greater than 0.1 , the 2 main effects, soybean type and particle size, were analyzed. If $P<0.1$ for this interaction, then GC versus GP, and $\mathrm{WC}$ versus WP, were analyzed instead as the main effects do not 
provide sufficient information when an interaction is present.

\section{RESULTS AND DISCUSSION}

In accordance with the objectives of the experiments, the FA profiles of the soybeans were very different (Table 2). Diets with added soybeans exceeded the amount of total UFA ( $<3.5 \%$; Jenkins and Harvatine, 2014) that is commonly considered appropriate to include in diets of lactating dairy cows.

Intake was not affected by dietary fat source in experiment 1 , or by fat source or concentration in experiment 2 . Intake is sometimes depressed when fat is added to the diet as oilseeds (Grant and Weidner, 1992; Petit and Cortes, 2010), but not always (Schingoethe et al., 1996). Additionally, when pure fat is added to the diet as an oil, there is not always a DMI response (He et al., 2012; Stoffel et al., 2015). Milk production effects in this experiment were therefore not attributable to changes in DMI. As is typical throughout our results there was not an effect of parity $(P>0.10)$ on DMI due to the inclusion of a covariate for experiment 1.

In experiment 1 there was an interaction between parity and treatment for milk fat yield, which informed our decision to analyze treatment effects within parity for this experiment. A parity by treatment interaction was not observed in experiment 2 and thus effects within parity are not reported. Few significant parity effects were seen in experiment 1 because much of the parity effect was encompassed in the covariate effect. Multiparous cows fed WP yielded more milk fat than MP cows fed WC $(P=0.05$; Table 3$)$. The increased milk fat secretion for MP cows in experiment 1 was due to increased $18 \mathrm{C}$ milk FA, with no change in secretion of shorter chain milk FA (Table 4; Supplemental Tables S1, S2, S3, and S4, https://doi.org/10.3168/jds.2018 -14498). This is not consistent with our hypothesized mode of action, as we would have expected greater de novo FA concentration when OA replaced LA. Experiment 2 also found that cows fed Plenish soybeans yielded greater milk fat, but only when the soybeans were ground $(P=0.01$; Table 5$)$. This may be because there was more rapid availability of oil to the rumen environment with ground soybeans compared with whole soybeans so the negative effects of oil were increased. In experiment 2 the inclusion of soybeans in the diet did not affect milk fat yield or concentration compared with LF $(P>0.17)$. This is due to the balance between the lower yield in SCFA that is seen during inhibition of milk fat synthesis and the greater yield of LCFA due to increased availability (Table 6; Supplemental Tables S5, S6, S7, and S8, https://doi.org/10.3168/jds .2018-14498). Ground Plenish beans resulted in an in- crease of $0.4 \%$ in milk fat concentration compared with ground conventional beans, and supported $150 \mathrm{~g}$ more daily milk fat secretion, supporting our hypothesis that a higher OA diet will result in less MFD compared with a high LA diet even when the supplemented FA are in oilseeds if the seed is ground. In agreement, the current literature describes greater milk fat for cows fed OA diets relative to high LA diets when free oils are supplemented (Kelly et al., 1998; He et al., 2012; Stoffel et al., 2015). The lower yield of milk fat for LA compared with OA diets has also been demonstrated using fullfat oilseeds of different types, though there is generally more variability in the response (Beauchemin et al., 2009; Lopes et al., 2017). In support of this increased variability for responses to oilseeds compared with free oils, our experiments show evidence for increased milk fat yield with WP versus WC only for MP cows in experiment 1, and not for PP cows in experiment 1, nor either parity in experiment 2. This is true even though in experiment 2, both the WC and WP showed numerically less SCFA yield and more LCFA yield than the low fat control diet (Table 6) as did cows on diets with added free oils. The negative effects of UFA are not as great when feeding full-fat oilseeds compared with free oils (Mohamed et al., 1988). The lesser effects of oilseeds compared with free oils contributes to the variation in the milk fat content and yield responses when full-fat oilseeds of varying FA profiles are fed rather than free oils.

In experiment 1 treatments did not affect milk fat yield or content $(P>0.10)$ in PP cows. The lack of a parity by treatment interaction in experiment 2 may be due to greater production and DMI of PP cows such that they were equivalent to the production of MP cows in experiment 1 . However, no mechanistic theory is proposed at this time. It has been previously noted that differences in particle size of soybeans results in different degrees of digestion (Dhiman et al., 1997). We did not collect data to determine if there were differences in digestion between the PP and MP cows that might have affected MFD, but minimal differences are generally observed (Yang et al., 1997; Kuehn et al., 1999). Although the effect of soybean FA profile of whole beans on milk fat yield may be minor, the difference is important when the soybeans are fed ground, making the oil more readily available to the rumen environment.

Unexpectedly, the yield of SCFA and C16 in experiment 1 were not decreased for the MP cows fed WC compared with those fed WP $(P>0.75)$; Table 4$)$. This contrasts with what is commonly observed in other studies where lower milk fat was related to a lower yield of SCFA (Baumgard et al., 2002; He et al., 2012). Despite the lack of difference in SCFA yield, there was 
Table 3. Least squares means for production and intake parameters for experiment $1^{1}$

\begin{tabular}{|c|c|c|c|c|c|c|c|c|c|c|}
\hline Variable & \multicolumn{2}{|c|}{ Multiparous } & \multicolumn{2}{|c|}{ Primiparous } & SE & \multicolumn{5}{|c|}{$P$-value ${ }^{2}$} \\
\hline DMI $(\mathrm{kg} / \mathrm{d})$ & 26.5 & 26.8 & 22.7 & 23.5 & 0.9 & 0.30 & 0.99 & 0.61 & & \\
\hline Fat $(\%)$ & 3.84 & 4.07 & 4.13 & 4.08 & 0.10 & 0.45 & 0.44 & 0.08 & & \\
\hline Protein (\%) & 3.05 & 3.06 & 2.97 & 3.03 & 0.05 & 0.41 & 0.75 & 0.53 & & \\
\hline Lactose (\%) & 4.97 & 5.01 & 5.10 & 5.17 & 0.06 & 0.32 & 0.19 & 0.84 & & \\
\hline Lactose $(\mathrm{kg} / \mathrm{d})$ & 2.25 & 2.26 & 2.08 & 1.99 & 0.07 & 0.48 & 0.27 & 0.40 & & \\
\hline Milk (Mcal/d) & 32.3 & 33.9 & 30.4 & 29.0 & 1.2 & 0.91 & 0.77 & 0.12 & & \\
\hline
\end{tabular}

${ }^{1} \mathrm{WC}=$ whole conventional; WP $=$ whole Plenish (Dupont-Pioneer, Johnston, IA); LSM were adjusted based on the covariate mean of MP and $\mathrm{PP}$ animals separately due to the use of the covariate effect in the model.

${ }^{2}$ Trt $=$ treatment; Ixn = interaction of parity and treatment; MP Trt = main effect within multiparous cows; PP Trt = main effect within primiparous cows.

a greater yield $(P<0.01)$ of $18 \mathrm{C}$ FA by MP cows fed WP compared with those fed WC. In agreement with experiment 1, in experiment 2 no significant effect of soybean type on the SCFA and C16 yield was observed $(P>0.13$; Table 6$)$. A main effect of soybean particle size $(P=0.03)$ was present on $\mathrm{C} 16$ yield. A particle size by soybean type interaction $(P=0.04)$ was observed, as well as a significantly $(P<0.03)$ greater $\mathrm{C} 18$ yield by cows fed GP compared with those fed GC. Though we did not analyze for expression of genes responsible for FA synthesis, FA transport, or triglyceride esterification and packaging in our experiments, our data suggest a similar level of depression of SCFA synthesis by diets high in OA and LA, whereas the efficiency of LCFA uptake is not negatively affected to the same degree by high OA diets compared with LA diets. In contrast, an in vitro experiment by Ma and Corl (2012) noted less downregulation of LCFA transport genes than SCFA synthesis genes when SREBP-1, known to be downregulated by $t 10, c 12$ CLA, was inhibited, which contradicts the milk FA profiles that we observed. It should be noted that the seemingly contradictory changes in the proportions of FA compared with the yield results in experiment 1 are due to the fact that the SCFA yield was not different whereas the C18 yield was greater in cows fed the WP diet. All the soybean-supplemented diets do demonstrate the general change toward a greater proportion and yield of 18C FA compared with LF due to the increased availability, which agrees with previous work (He et al., 2012; Stoffel et al., 2015).

Table 4. Milk fatty acid (FA) composition (LSM) and yield for experiment $1^{1}$

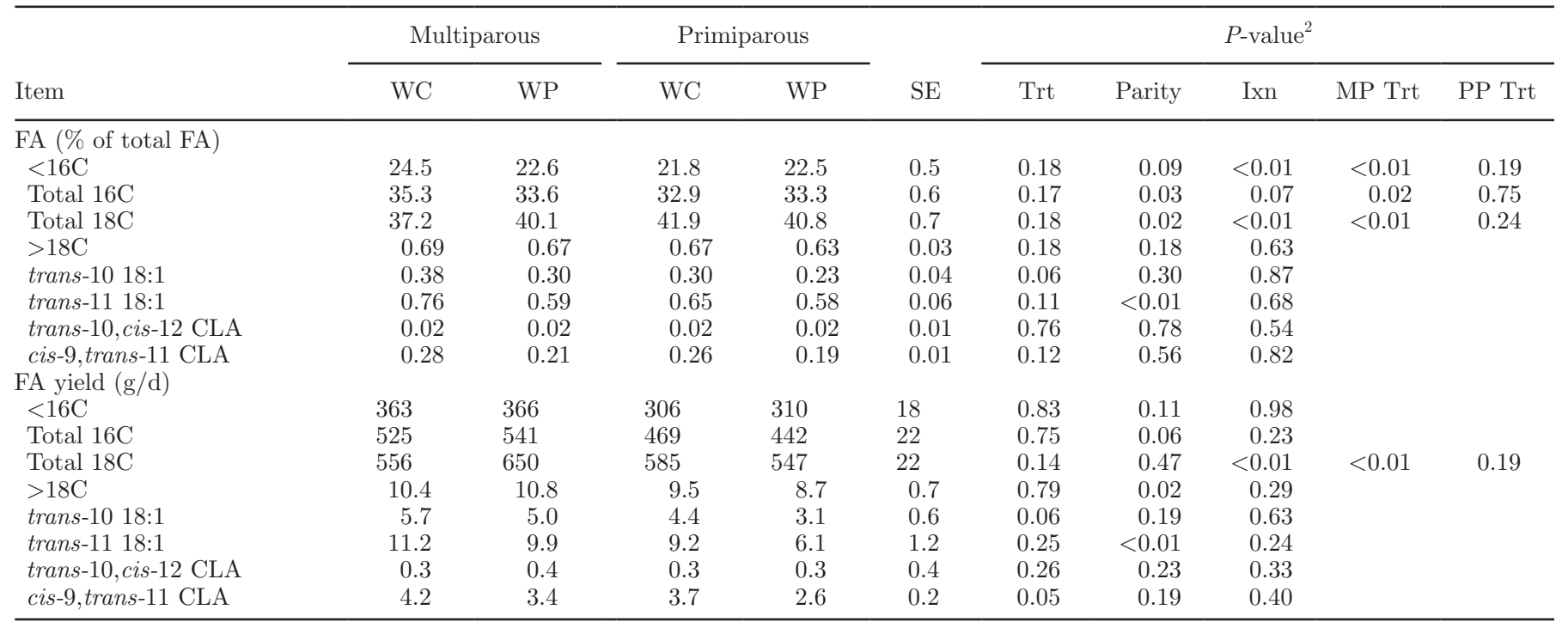

${ }^{1} \mathrm{WC}=$ whole control; $\mathrm{WP}=$ whole Plenish (Dupont-Pioneer, Johnston, IA).

${ }^{2} \mathrm{Trt}=$ treatment; Ixn $=$ interaction of treatment and parity; MP Trt $=$ treatment effect within multiparous cows; PP trt $=$ treatment effect within primiparous cows. 
Table 5. Least squares means for production and intake parameters for experiment 2

\begin{tabular}{|c|c|c|c|c|c|c|c|c|c|c|c|c|}
\hline Variable & \multicolumn{5}{|c|}{ Treatment $^{1}$} & $\mathrm{SE}$ & \multicolumn{6}{|c|}{$P$-value ${ }^{2}$} \\
\hline Milk (kg/d) & 48.0 & 48.8 & 47.2 & 48.5 & 46.8 & 1.0 & 0.80 & 0.87 & & & 0.58 & $<0.01$ \\
\hline Fat $(\%)$ & 3.25 & 3.09 & 3.50 & 3.40 & 3.53 & 0.16 & 0.17 & 0.10 & 0.28 & $<0.01$ & & \\
\hline Protein (\%) & 3.18 & 3.09 & 3.18 & 3.08 & 3.13 & 0.04 & 0.06 & 0.35 & & & 0.24 & 0.01 \\
\hline Protein $(\mathrm{kg} / \mathrm{d})$ & 1.51 & 1.50 & 1.49 & 1.49 & 1.40 & 0.03 & 0.11 & 0.55 & & & 0.23 & 0.19 \\
\hline Lactose $(\mathrm{kg} / \mathrm{d})$ & 2.37 & 2.43 & 2.37 & 2.42 & 2.34 & 0.05 & 0.61 & 0.63 & & & 0.41 & 0.01 \\
\hline Milk (Mcal/d) & 32.2 & 31.9 & 33.0 & 33.0 & 32.6 & 0.87 & 0.48 & 0.40 & & & 0.19 & 0.70 \\
\hline
\end{tabular}

${ }^{1} \mathrm{LF}=$ low fat; $\mathrm{GC}=$ ground conventional; GP = ground Plenish $($ Dupont-Pioneer, Johnston, IA); WC = whole conventional; WP $=$ whole Plenish.

${ }^{2}$ Fat $=$ LF vs. all soybean diets; Ixn $=$ interaction of bean type and particle size; particle size $=$ particle size main effect; Plenish $=$ bean variety main effect.

Despite the differences in fat yield between treatments, no differences $(P>0.26)$ were present in proportion or yield of $t 10, c 12$ CLA between soybean types in either experiment. Trans-10,cis-12 CLA has been shown to have potent effects on milk fat (Lock et al., 2007; Shingfield et al., 2009), so it was expected that it would be different between treatments with differences in milk fat yield. The conventional soybean treatments were much higher in LA, a precursor to $t 10, c 12$ CLA, so it was expected that they would have a higher proportion of $t 10, c 12$ CLA. The lack of an effect of soybean type on milk $t 10, c 12$ CLA suggests that there are more FA acting on the mammary gland to cause
MFD than just $t 10, c 12$ CLA. This suggestion is supported by infusion studies with different CLA isomers (Saebo et al., 2005; Perfield et al., 2006, 2007) that demonstrate changes in milk fat secretion. However, the biological significance of these CLA isomers has not been determined as they are secreted in smaller amounts than $t 10, c 12$ CLA. The lack of differences in $t 10, c 12$ CLA between treatments $(P>0.10)$ may also suggest that high levels of OA can influence the upstream biohydrogenation pathways. This could happen due to having overwhelmed the step from 18:1 isomers to stearic acid causing feedback inhibition of biohydrogenation of CLA.

Table 6. Milk fatty acid (FA) composition and yield (LSM) for experiment 2

\begin{tabular}{|c|c|c|c|c|c|c|c|c|c|c|c|c|}
\hline \multirow[b]{2}{*}{ Item } & \multicolumn{5}{|c|}{ Treatment $^{1}$} & \multirow[b]{2}{*}{$\mathrm{SE}$} & \multicolumn{6}{|c|}{$P$-value ${ }^{2}$} \\
\hline & $\mathrm{LF}$ & $\mathrm{GC}$ & GP & WC & WP & & Fat & Ixn & $\begin{array}{c}\text { WP } \\
\text { vs. WC }\end{array}$ & $\begin{array}{c}\text { GP } \\
\text { vs. GC }\end{array}$ & $\begin{array}{l}\text { Particle } \\
\text { size }\end{array}$ & Plenish \\
\hline \multicolumn{13}{|l|}{ FA ( $\%$ of total FA) } \\
\hline$<16 \mathrm{C}$ & 26.3 & 21.9 & 22.1 & 22.1 & 22.5 & 0.68 & $<0.01$ & 0.84 & & & 0.60 & 0.58 \\
\hline Total 16C & 32.5 & 27.4 & 27.2 & 27.9 & 28.5 & 0.61 & $<0.01$ & 0.50 & & & 0.12 & 0.65 \\
\hline Total 18C & 34.4 & 46.4 & 46.1 & 45.8 & 44.3 & 1.20 & $<0.01$ & 0.55 & & & 0.25 & 0.37 \\
\hline trans-11 18:1 & 0.63 & 1.01 & 0.65 & 0.92 & 0.55 & 0.05 & $<0.01$ & 0.97 & & & 0.04 & $<0.01$ \\
\hline trans-10, cis-12 CLA & 0.05 & 0.08 & 0.07 & 0.07 & 0.07 & 0.01 & $<0.01$ & 0.95 & & & 0.14 & 0.45 \\
\hline cis-9,trans-11 CLA & 0.34 & 0.54 & 0.42 & 0.51 & 0.35 & 0.03 & $<0.01$ & 0.37 & & & 0.07 & $<0.01$ \\
\hline \multicolumn{13}{|l|}{ FA yield $(\mathrm{g} / \mathrm{d})$} \\
\hline$<16 \mathrm{C}$ & 355 & 290 & 322 & 319 & 325 & 21 & $<0.01$ & 0.31 & & & 0.21 & 0.14 \\
\hline Total 16C & 439 & 357 & 391 & 400 & 406 & 24 & $<0.01$ & 0.30 & & & 0.03 & 0.13 \\
\hline Total 18C & 461 & 591 & 652 & 645 & 624 & 27 & $<0.01$ & 0.04 & 0.46 & 0.03 & & \\
\hline
\end{tabular}

${ }^{1} \mathrm{LF}=$ low fat; $\mathrm{GC}=$ ground conventional; GP $=$ ground Plenish $($ Dupont-Pioneer, Johnston, IA); WC = whole conventional; WP $=$ whole Plenish.

${ }^{2}$ Fat $=$ LF vs. all soybean diets; Ixn $=$ interaction; particle size $=$ particle size main effect; Plenish $=$ bean variety main effect. 
Another possible pathway by which UFA may be influencing milk fat is through t10 18:1. During experiment 1 t10 18:1 proportion and yield tended to be greater $(P=0.06)$ in the milk fat of both $\mathrm{PP}$ and MP cows fed WC compared with those fed WP. In agreement, experiment 2 demonstrated a main effect $(P<0.01)$ of soybean type on $t 1018: 1$ yield and proportion where conventional soybean diets resulted in a greater proportion and yield compared with diets containing Plenish soybeans. There was also a main effect of soybean particle size $(P=0.01)$ where the ground soybeans resulted in more $t 10$ 18:1 yield and proportion, and greater trans-11 18:1 proportion, than did the whole soybeans. It has been demonstrated that $t 10$ 18:1 is a bioactive FA, less potent than $t 10, c 12$ CLA, when infused (Shingfield et al., 2009), as well as in mammary epithelial cell culture (Kadegowda et al., 2009). However, a study infusing less $t 10$ 18:1 than Shingfield et al. (2009) found no effect of t10 18:1 on MFD (Lock et al., 2007). However, Shingfield et al. (2009) raised t10 18:1 in milk to $4.4 \mathrm{~g} / 100 \mathrm{~g}$ of FA compared with the $1.1 \mathrm{~g} / 100 \mathrm{~g}$ of FA in Lock et al. (2007). Whether the change in proportion of $t 1018: 1$ in our experiments $(0.2-3.1 \mathrm{~g} / 100 \mathrm{~g}$ of FA) was enough to cause changes in milk fat yield is debatable, it is certainly indicative of changes in the biohydrogenation pathways in the rumen which produce CLA that contribute to changes in the gene regulation of milk fat synthesis. Alterations in the biohydrogenation pathways are further supported by greater proportion of trans-11 18:1 in experiment 2 due to conventional soybeans $(P<0.01)$, though in experiment 1 the difference did not reach statistical significance $(P=0.11)$. This pattern holds true for the majority of the trans FA (Supplemental Tables S2 and S6; https://doi.org/10.3168/jds.2018-14498).

All diets in experiment 2 lacked adequate fiber length, which could have contributed to overall lower milk fat compared with what was observed for experiment 1 . On average, there was less than $1.4 \%$ of the TMR on the top screen $(19 \mathrm{~mm})$ of the Penn State shaker box (Nasco, Fort Atkinson, WI) and less than 32 and $42 \%$ on the second screen $(8 \mathrm{~mm})$ for ground and whole soybean diets, respectively. This particle size distribution does not meet the recommendations of Heinrichs and Kononoff (2002). The proportions and yields of $t 1018: 1$ and $t 10, c 12$ CLA were greater in the second experiment compared with the first, which agrees with the lower milk fat concentrations observed in all treatments compared with experiment 1 . It has been shown that over half of recovery from MFD occurs within 2 wk (Rico and Harvatine, 2013); thus, the short periods should not have affected this response.

Unexpectedly, cows fed the Plenish diets yielded less $(P \leq 0.01)$ milk and lactose compared with cows fed the conventional diets in experiment 2 (47.0 vs. 48.6 and 2.35 vs. $2.42 \mathrm{~kg} / \mathrm{d}$, respectively), which aligns with previous research (Lopes et al., 2017). We have no explanation for the difference as to the best of our knowledge the soybeans fed were closely related cultivars except for their FA profile differences. The difference in protein level of the soybeans was balanced with soybean meal, which should not result in differences in the dietary AA profile. Although a difference was observed in CP between the diets due to soybean variation, the protein yields were not different between treatments because Plenish soybeans had a significant positive effect on protein percent (3.05 and $3.18 \%$ for conventional and Plenish, respectively) that countered the decrease in milk yield, which suggests that protein was not limiting.

Beyond the implications of this research for the feeding of soybeans to dairy cattle, consideration must also be given to the influence of internal native oils in other dairy cattle feeds, especially those that are routinely subjected to mechanical processing. Corn is the main source of FA, specifically LA, in most lactating cow diets when supplemental fat or oilseeds are not added. There is an opportunity for a decrease in dietary LA if the FA profile of corn was altered. This could result in an increase in milk fat yield even in low fat diets (Stoffel et al., 2015). More research is necessary in this area to understand the interactions between FA profile, oil availability and other dietary characteristics to take full advantage of the ability to manipulate secretion of milk fat and milk FA profile.

\section{CONCLUSIONS}

The development of Plenish soybeans allowed us to test our hypothesis that feeding full-fat soybeans high in OA would result in greater milk fat yield than feeding conventional full-fat soybeans high in LA. Any positive effect of high OA in whole soybeans was small and not totally consistent in these experiments, and the increased fat yield for MP cows in experiment 1 was associated with greater C18 milk FA and with no effect on de novo FA, which was contrary to expected results. However, ground Plenish soybeans clearly increased milk fat relative to ground conventional beans with increases across all milk FA chain lengths. Also, further research on these effects should be done to explain the decrease in milk yield that was demonstrated by the Plenish diets and better understand the interaction of oilseed FA profile with other dietary characteristics. In addition, the effect of FA profile and particle size of other dairy feeds that deliver considerable FA to the diet, due to high FA concentration or high feed inclusion rates, should be investigated. 


\section{ACKNOWLEDGMENTS}

The authors thank Sandy Bertics at the University of Wisconsin for her technical assistance. We also thank Dupont-Pioneer for the donation of the Plenish soybeans and to UW-Madison Hatch funding (project number: WIS01595), and USDA Feed Efficiency (award number: 2011-68004-30340) for the funding for this project.

\section{REFERENCES}

AOAC International. 2012. Official Methods of Analysis. 19th ed. AOAC Int., Arlington, VA.

Baumgard, L. H., E. Matitashvili, B. A. Corl, D. A. Dwyer, and D. E. Bauman. 2002. trans-10, cis-12 conjugated linoleic acid decreases lipogenic rates and expression of genes involved in milk lipid synthesis in dairy cows. J. Dairy Sci. 85:2155-2163.

Beauchemin, K. A., S. M. McGinn, C. Benchaar, and L. Holtshausen. 2009. Crushed sunflower, flax, or canola seeds in lactating dairy cow diets: Effects on methane production, rumen fermentation, and milk production. J. Dairy Sci. 92:2118-2127.

Chouinard, P. Y., L. Corneau, A. Saebo, and D. E. Bauman. 1999. Milk yield and composition during abomasal infusion of conjugated linoleic acids in dairy cows. J. Dairy Sci. 82:2737-2745.

Dhiman, T. R., A. C. Korevaar, and L. D. Satter. 1997. Particle size of roasted soybeans and the effect on milk production of dairy cows. J. Dairy Sci. 80:1722-1727.

Dorea, J. R. R., and L. E. Armentano. 2017. Effects of common dietary fatty acids on milk yield and concentrations of fat and fatty acids in dairy cattle. Anim. Prod. Sci. 57:2224-2236.

Grant, R. J., and S. J. Weidner. 1992. Effect of fat from whole soybeans on performance of dairy-cows fed rations differing in fiber level and particle-size. J. Dairy Sci. 75:2742-2751.

Griinari, J. M., D. A. Dwyer, M. A. McGuire, D. E. Bauman, D. L. Palmquist, and K. V. V. Nurmela. 1998. Trans-octadecenoic acids and milk fat depression in lactating dairy cows. J. Dairy Sci. 81:1251-1261.

Hall, M. B. 2015. Determination of dietary starch in animal feeds and pet food by enzymatic colorimetric method: Collaborative study. J. AOAC Int. 98:397.

He, M., K. L. Perfield, H. B. Green, and L. E. Armentano. 2012. Effect of dietary fat blend enriched in oleic or linoleic acid and monensin supplementation on dairy cattle performance, milk fatty acid profiles, and milk fat depression. J. Dairy Sci. 95:1447-1461.

Heinrichs, A. J., and P. J. Kononoff. 2002. Evaluating particle size of forages and TMRs using the new Penn State forage particle separator. DAS 02-42. Technical Bulletin of the Pennsylvania State University, College of Agricultural Sciences. Cooperative Extension.

Jenkins, T. C., and K. J. Harvatine. 2014. Lipid feeding and milk fat depression. Vet. Clin. North Am. Food Anim. Pract. 30:623-642.

Kadegowda, A. K. G., M. Bionaz, L. S. Piperova, R. A. Erdman, and J. J. Loor. 2009. Peroxisome proliferator-activated receptorgamma activation and long-chain fatty acids alter lipogenic gene networks in bovine mammary epithelial cells to various extents. J. Dairy Sci. 92:4276-4289.

Kelly, M. L., J. R. Berry, D. A. Dwyer, J. M. Griinari, P. Y. Chouinard, M. E. Van Amburgh, and D. E. Bauman. 1998. Dietary fatty acid sources affect conjugated linoleic acid concentrations in milk from lactating dairy cows. J. Nutr. 128:881-885.

Khiaosa-Ard, R., M. Kreuzer, and F. Leiber. 2015. Apparent recovery of $\mathrm{C} 18$ polyunsaturated fatty acids from feed in cow milk: A meta-analysis of the importance of dietary fatty acids and feeding regimens in diets without fat supplementation. J. Dairy Sci. 98:6399-6414.
Kuehn, C. S., J. G. Linn, D. G. Johnson, H. G. Jung, and M. I. Endres. 1999. Effect of feeding silages from corn hybrids selected for leafiness or grain to lactating dairy cattle. J. Dairy Sci. 82:2746-2755.

Lock, A. L., C. Tyburczy, D. A. Dwyer, K. J. Harvatine, F. Destaillats, Z. Mouloungui, L. Candy, and D. E. Bauman. 2007. Trans-10 octadecenoic acid does not reduce milk fat synthesis in dairy cows. J. Nutr. 137:71-76.

Lopes, J. C., M. T. Harper, F. Giallongo, J. Oh, L. Smith, A. M. Ortega-Perez, S. A. Harper, A. Melgar, D. M. Kniffen, R. A. Fabin, and A. N. Hristov. 2017. Effect of high-oleic-acid soybeans on production performance, milk fatty acid composition, and enteric methane emission in dairy cows. J. Dairy Sci. 100:1122-1135.

Ma, L., and B. A. Corl. 2012. Transcriptional regulation of lipid synthesis in bovine mammary epithelial cells by sterol regulatory element binding protein-1. J. Dairy Sci. 95:3743-3755.

Mohamed, O. E., L. D. Satter, R. R. Grummer, and F. R. Ehle. 1988 Influence of dietary cottonseed and soybean on milk production and composition. J. Dairy Sci. 71:2677-2688.

Mosley, E. E., G. L. Powell, M. B. Riley, and T. C. Jenkins. 2002. Microbial biohydrogenation of oleic acid to trans isomers in vitro. J. Lipid Res. 43:290-296.

NRC. 2001. Nutritional Requirements of Dairy Cattle. 7th rev. ed. Natl. Acad. Sci. Washington, DC.

Owens, F. N., D. S. Secrist, W. J. Hill, and D. R. Gill. 1998. Acidosis in cattle: A review. J. Anim. Sci. 76:275-286.

Perfield, J. W., P. Delmonte, A. L. Lock, M. P. Yurawecz, and D. E. Bauman. 2006. Trans-10, trans-12 conjugated linoleic acid does not affect milk fat yield but reduces Delta(9)-desaturase index in dairy cows. J. Dairy Sci. 89:2559-2566.

Perfield, J. W., A. L. Lock, J. M. Griinari, A. Saebo, P. Delmonte, D. A. Dwyer, and D. E. Bauman. 2007. Trans-9, cis-11 conjugated linoleic acid reduces milk fat synthesis in lactating dairy cows. J. Dairy Sci. 90:2211-2218.

Petit, H. V., and C. Cortes. 2010. Milk production and composition, milk fatty acid profile, and blood composition of dairy cows fed whole or ground flaxseed in the first half of lactation. Anim. Feed Sci. Technol. 158:36-43.

Rico, D. E., and K. J. Harvatine. 2013. Induction of and recovery from milk fat depression occurs progressively in dairy cows switched between diets that differ in fiber and oil concentration. J. Dairy Sci. 96:6621-6630.

Saebo, A., P. Saebo, J. M. Griinari, and K. J. Shingfield. 2005. Effect of abomasal infusions of geometric isomers of 10,12 conjugated linoleic acid on milk fat synthesis in dairy cows. Lipids 40:823-832.

Schingoethe, D. J., M. J. Brouk, K. D. Lightfield, and R. J. Baer. 1996. Lactational responses of dairy cows fed unsaturated fat from extruded soybeans or sunflower seeds. J. Dairy Sci. 79:1244-1249.

Shingfield, K. J., A. Saebo, P. C. Saebo, V. Toivonen, and J. M. Griinari. 2009. Effect of abomasal infusions of a mixture of octadecenoic acids on milk fat synthesis in lactating cows. J. Dairy Sci. 92:4317-4329.

Stoffel, C. M., P. M. Crump, and L. E. Armentano. 2015. Effect of dietary fatty acid supplements, varying in fatty acid composition, on milk fat secretion in dairy cattle fed diets supplemented to less than 3\% total fatty acids. J. Dairy Sci. 98:431-442.

Sukhija, P. S., and D. L. Palmquist. 1988. Rapid method for determination of total fatty acid content and composition of feedstuffs and feces. J. Agric. Food Chem. 36:1202-1206.

Weimer, P. J., D. M. Stevenson, and D. R. Mertens. 2010. Shifts in bacterial community composition in the rumen of lactating dairy cows under milk fat-depressing conditions. J. Dairy Sci. 93:265278.

Yang, W. Z., K. A. Beauchemin, B. I. Farr, and L. M. Rode. 1997. Comparison of barley, hull-less barley, and corn in the concentrate of dairy cows. J. Dairy Sci. 80:2885-2895. 